\title{
Determinant Factors of Profitability in Malaysia's Real Estate Investment Trusts (M-REITS)
}

\author{
Shaharudin Jakpar, Michael Tinggi, Akmal Hisham Tak and Nur Amanina Ruzlan \\ Faculty of Economics and Business, Universiti Malaysia Sarawak (UNIMAS)
}

\begin{abstract}
The performance of Real Estate Investment Trust (REIT) can be literarily explained in terms of its operational success which is revealed in its profitability to the investors (Grupe \& DiRocco, 1999). A company's success in investments is usually measured by its profitability. The objective of this study is to examine the role of determinant factors towards the profitability of M-REITs. This research was conducted using procedures of panel data for a total sample of 8 Malaysia's Real Estate Investment Trusts (M-REITs) for a period of 8 years, starting from 2008 until 2015. The profitability of M-REITs was measured by the return on equity (ROE) as the dependent variable, whereas the determinant factors for M-REITs' profitability are dividend yield (DY), net asset value (NAV) and price earnings ratio (PER) as the independent variables. The outcome from the research revealed that only dividend yield (DY) has a positive significant relationship with M-REITs profitability, and no significant relationship was found between both net asset value (NAV) and price earnings ratio (PER) towards M-REITs profitability.
\end{abstract}

Keywords: Real Estate Investment Trust (REIT), Profitability, return on equity, dividend yield, net asset value, price earnings ratio.

\section{INTRODUCTION}

A stock market is a virtual form of intermediation where buyers and sellers can trade their assets such as shares and company securities (Reilly \& Keith, 2012). Stock market has played a crucial role which determine the price of underlying assets at any particular time by matching all the available information. When there are buyers and sellers who are willing to participate in trade in an asset, stock market works. High demand of an asset will cause the value of the asset to rise. The first stock market was initially developed in London in 1606 which means the stock market has roughly over 400 year of histories. Today, due to the advancement of technology, the stock markets have risen to become extensive exchanges of capital and funding, trading in trillions $24 / 7$ across the world. Real estate is considered to be one of the largest sectors within the economies, and yet to be the portent in several financial crises during the past decades. Therefore, to conduct a research on this sector would be beneficial for many, especially for investors to understand what real estate can really offer them and to see its potential in the present and future market. According to Yee et al. (2011), investments in real estate can be done by owning any physical properties or to invest in any property stocks that are listed publicly as well as debt securities that are related to property such as bonds that are issued on developing property projects. The continuous financial innovation has made the investment spectrum expanded within the real estate sector with the development of Real Estate Investment Trusts.

A real estate investment trust (REIT) is a type of public company that invests or finances in real estate whether through purchasing properties or mortgages. REITs trade their shares in the major stock exchange and can be highly attractive to income-seeking investors as one of the asset class investment options due to the fact that REITs usually distribute a minimum of $90 \%$ of their taxable income as dividends to their shareholders. Investors also seek to invest and own a share in REITs as it can be said to be less risky with indirectly own a property and able to provide high dividend yields. According to Alias 
and Soi (2011), the source of income generation for REITs comes from owning and operating real property that produces a good return of investment such as office buildings, shopping complexes and service apartments. Stocks in REITs can held privately or to be traded publicly on stock exchanges. Apart from that, REITs may also invest in real estate-related securities, cash or fixed deposit and whole loans. Hence, most of the earnings that REITs received are the collected recurrent rental income from the rental operation of the owned real properties. Funds from REITs are also entitled to be invested in assets that are related to non-real estate or other assets that are liquid with a limited investment amount authorized by a regulatory body. From the net income generated by REITs, the shareholders or unit holders would receive dividends as their returns of investment and or any capitals gained throughout the holding period.

According to Ong et al. (2011), the industry of REITs has been further classified into various segments that are based on different categories of functional property such as retail, industrial, hotel, residential, office, healthcare, and diversified REIT. This type of property classification can be helpful to investors to analyse each of every REIT sector's performance. REITs can be considered as units of trust funds that are being managed by a professional body (Alias \& Soi, 2011).

The beginning of Asian's REITs started in 2001 with REITs from Japan, Singapore, Hong Kong, South Korea, Taiwan and Malaysia. According to the Asia Pacific Real Estate Association (APREA) report, as mentioned by Professor Graeme Newell, most of the Asian REIT markets reached lower risk, higher returns, and superior risk-adjusted performance than their respective stock markets, especially since the occurrence of the global financial crisis (APREA, 2012). In addition to that, in 2004, a survey done by Jones Lang LaSalle also proved that the transparency and maturity level in most real estate markets around Asia such as Japan, Malaysia, Singapore, and Hong Kong had shown substantial enhancement since the Asia financial crisis occurred in 1997. Therefore, the appearance of REITs in Asia provide new opportunities for international real estate security funds to expand themselves into Asia's real estate asset market, apart from offering them long-term diversification benefits within their portfolios.

REITs in Malaysia were formerly known as listed property trusts and Malaysia was the first Asian country to establish property trusts. The first acknowledged property trust that was listed on the Kuala Lumpur Stock Exchange (KLSE) was Arab Malaysian Property Trust in September 1989, and then followed by First Malaysian Property Trust in November 1989. A year later in December 1990, Amanah Harta Tanah PNB was listed, and then followed by the unlisted Mayban Property Trust Fund One in the same year. Later then, no listed property trusts were issued up until March 1997 when Amanah Harta Tanah PNB 2 was listed. However, institutional investors found these property trusts were not that popular and gave slight responses towards the public listings (Newell, Ting and Acheampong, 2002). Back then in 1986, Negara Malaysia (BNM) was very restrictive in approving the regulatory framework and the REITs net income were not provided with tax transparency. Other issues that caused the sector to be hindered were insufficient attention on asset management, potential conflicts of interest and relatively thin trading volume. Even when Bank Negara Malaysia gave a revision of the property trust guidelines in 1995, it failed to initiate and attract the domestic investors' interests. According to Rohaya and Hishamuddin (2015), the development of REITs in Malaysia has been intensified in 2006 after the Malaysian Securities Commission (SC) issued the REIT Guideline by in 2005.

It has been stated that in order for Malaysian REITs to be formed, a minimum fund size is RM 100 million is needed. The management company has entitlement to foreign effective equity, limited to the maximum of 70\% (Ong et al., 2011). Later in 2005, there were continuous additional listings of M-REITs following to REITs guidelines that had been further revised, with Axis REIT being the first new REIT listed in the main board of KLSE in August 2005. A year later in August 2006, it was announced that Malaysia was the world's first developer of Islamic REIT that is in compliance with Shariah principle and facilitated by the guidelines that was issued by the Security Commission of Malaysia. The guidelines had introduced new benchmark worldwide for the growth of Islamic REITs, thus further improved the vital 
role of Malaysia in promoting the growth of Islamic market in the International Financial Community. As at 2010, three Islamic REITs were established namely Axis REIT, Al-Hadharah Boustead REIT and AlAqar KPJ REIT, which then in December 2008, Axis REIT converted to Islamic REIT. An additional of two REITs that was listed in Bursa Malaysia in 2010 were Sunway City REIT, which is known to be the largest IPO of REIT in Malaysia, and CapitaMall Malaysia Trust REIT, the first foreign-sponsored REIT in Malaysia. As at 30th November 2016, there are 17 M-REITs that are listed by the Malaysian Securities Commission.

M-REITs can be said to be one of the newer investment instruments that was introduced in Malaysia. Hence, M-REITs market is seen to be relatively small when compared to its regional peers such as Taiwan, Singapore and Hong Kong. The asset size of M-REITs is too small to attract foreign fund. In terms of capital value, it can be considered too small regarding to the low exchange value of Ringgit. Also, the small capitalization of REIT market makes the larger investors unable to make consequential investment that can maintain its liquidity. As a result, investors argued that M-REITs had a slow growth in return. As reported by Rohaya and Hishamuddin (2015), there are also several factors of the M-REIT's characteristics that cause the underperformance, with evidence from the Bursa Malaysia referring on M-REITs price quotes' trend analysis. Those characteristics include the difference of property allocation, firm size, the location and REITs' capital structure which made investors feel difficult to judge upon M-REITs. Given REITs' growing relevance as investment instrument and the effort of attracting more domestic and foreign investments, it is worth to carry out the study to evaluate the determinant factors of profitability in M-REITs.

The main purpose of the study to be carried out is to examine the role of determinant factors towards the profitability of M-REITs. The research was to investigate the determinants of the profitability in M-REITs. The determinants that are being measured are dividend yield, net asset value, and price earnings ratio which is used as a proxy of stock market price. The profitability of M-REITs is measured in Return on Equity (ROE). There are few past researches that had been done on investigating the determinants and factors of REITs profitability and performance, be it in Malaysia and also other countries in different time periods. This study raises some research questions which can aid in the investigation of the determinant factors of M-REITs profitability. The questions that are going to be answered include:

i. Does the dividend yield, net asset value and stock market price can significantly effect to MREITs profitability?

ii. What is the relationship between dividend yield, net asset value, stock market price and the profitability of M-REITs?

iii. Among dividend yield, net asset value and stock market price, which is the main factor that is most significant to the profitability of M-REITs?

\section{LITERATURE REVIEW}

\section{Fundamental analysis}

Fundamental analysis is well known in examining how well a company performs in the industry and forecasts future earnings and stock price of a company.

\section{Fundamental of M-REITs}

According to Bursa Malaysia's website (http://www.bursamalaysia.com/market/derivatives/about-bursamalaysia-derivatives/about-us/company-profile), Bursa Malaysia is known as an exchange holding company approved under Section 15 of the Capital Markets and Services Act 2007. The Malayan Stock Exchange was established in 1960 for public trading of shares. Kuala Lumpur Stock Exchange (KLSE) 
Berhad was being incorporated as a company that took over the trading operations on KLSE in year 1976. Later in 2004, KLSE Berhad was then renamed to Bursa Malaysia Berhad, following the demutualization exercise. Their vision is to be the preferred partner in Asia for fund-raising, trading and investment by offering fair and systematic markets that allows investors to trade with varieties of products. On March 2005, Bursa Malaysia was listed on Main Board of Bursa Malaysia Securities Berhad which divided into three categories, namely securities clearing, derivatives and bonds. Later in December 2008, Bursa Trade Securities was launched, which enables faster processing and execution of orders and provides wider trading functions and features. In 2009, Bursa merged both the main board and the second board of Bursa Malaysia into a single market which is known as the Main Market while the Malaysian Exchange of Securities, Dealing \& Automated Quotation (MESDAQ) was renamed as Access, Certainty and Efficiency (ACE). Figure 1 shows the regulatory structure of Bursa Malaysia under the supervision of Securities Commission (SC) and Ministry of Finance (MOF).

Figure 1: Regulatory Structure

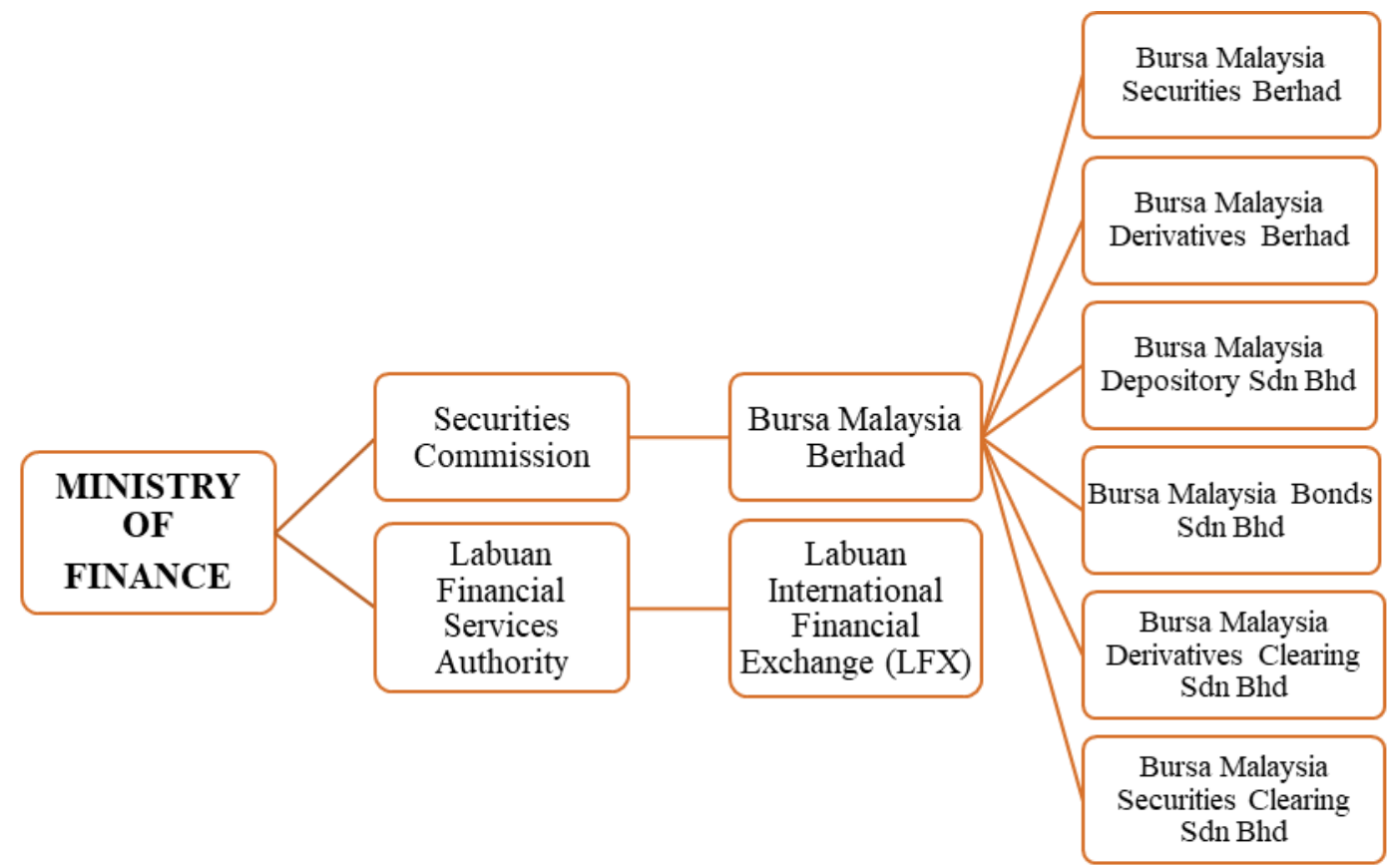

Source: Bursa Malaysia, 2017

(http://www.bursamalaysia.com/corporate/about-us/our-organisation/regulatory-structure/)

\section{The Development of Malaysia's Real Estate Investment Trusts (M-REITs)}

Real Estate Investment Trusts (REITs) can be said as an investment tools for investors to generate appealing returns, besides than investing in bonds, unit trust, shares and direct ownership of real property (Alias \& Soi, 2011). Normally, the REITs companies can be relied on a group of people which is professionally managed by a manager who is a registered valuer in order to make all investment decisions. Initially, REITs were established in the early 1960s in the United States. According to Hamzah, Rozali and Tahir (2010), the legislation to permit the formation of listed property trusts which was similar to REITs was first introduced in Malaysia, therefore making Malaysia to be the first Asian country to develop the Listed Property Trusts. From that, Arab Malaysian First Property Trust (AMFPT) was listed on Kuala Lumpur Stock Exchange (KLSE) on August 1989 being the first Listed Property Trust. Later, the second Listed Property Trusts was listed on the KLSE namely First Malaysian Property Trust (FMPT) which was launched in November 1989 followed by Amanah Harta Tanah PNB (AHTP) as the third LPT established 
in December 1990. Seven years later on March 1997, Mayban Property Trust Fund One (MPTF1) came as the fourth LPT to be listed on the KLSE. However, after thirteen years of being listed, on July 2002, FMPT terminated to be listed. By the end of April 2005, only three Listed Property Trusts were left on Bursa Malaysia namely Amanah Harta Tanah PNB, Amanah Harta Tanah PNB 2 and AmFirst Property Trust. Also in the same year of 2005, the Securities Commission introduced new guidelines on real estate investment trusts (REITs). In addition to that, the term listed property trust (LPT) was then renamed as Real Estate Investment Trust (REIT) with the purpose of standardising the term along with other countries. In 2005, Axis REIT which is the first Malaysian REIT was then listed on Bursa Malaysia.

Table 1: Listed Malaysia's REITs by the Security Commission of Malaysia prior November 2016

\begin{tabular}{|c|c|c|c|}
\hline No. & Funds Under Management & Trustee & Management Company \\
\hline 1 & $\begin{array}{l}\text { AmFirst Real Estate } \\
\text { Investment Trust }\end{array}$ & $\begin{array}{l}\text { Maybank Trustees } \\
\text { Berhad }\end{array}$ & $\begin{array}{l}\text { AmARA REIT Managers } \\
\text { Sdn Bhd }\end{array}$ \\
\hline 2 & $\begin{array}{l}\text { AmanahRaya Real Estate } \\
\text { Investment Trust }\end{array}$ & $\begin{array}{l}\text { CIMB Islamic Trustee } \\
\text { Berhad }\end{array}$ & $\begin{array}{l}\text { AmanahRaya-REIT } \\
\text { Managers Sdn Bhd }\end{array}$ \\
\hline 3 & $\begin{array}{l}\text { Axis Real Estate Investment } \\
\text { Trust }\end{array}$ & RHB Trustees Berhad & $\begin{array}{l}\text { Axis REIT Managers } \\
\text { Berhad }\end{array}$ \\
\hline 4 & Al-`Aqar Healthcare REIT & $\begin{array}{l}\text { AmanahRaya Trustees } \\
\text { Berhad }\end{array}$ & $\begin{array}{l}\text { Damansara REIT Managers } \\
\text { Sdn Bhd }\end{array}$ \\
\hline 5 & $\begin{array}{l}\text { IGB Real Estate Investment } \\
\text { Trust }\end{array}$ & $\begin{array}{l}\text { MTrustee Berhad } \\
\text { (formerly known as } \\
\text { AmTrustee Berhad) }\end{array}$ & $\begin{array}{l}\text { IGB REIT Management Sdn } \\
\text { Bhd }\end{array}$ \\
\hline 6 & $\begin{array}{l}\text { Atrium Real Estate } \\
\text { Investment Trust }\end{array}$ & Pacific Trustees Berhad & $\begin{array}{l}\text { Atrium REIT Managers Sdn } \\
\text { Bhd }\end{array}$ \\
\hline 7 & $\begin{array}{l}\text { Al-Salam Real Estate } \\
\text { Investment Trust }\end{array}$ & $\begin{array}{l}\text { AmanahRaya Trustees } \\
\text { Berhad }\end{array}$ & $\begin{array}{l}\text { Damansara REIT Managers } \\
\text { Sdn Bhd }\end{array}$ \\
\hline 8 & $\begin{array}{l}\text { Sunway Real Estate } \\
\text { Investment Trust }\end{array}$ & RHB Trustees Berhad & $\begin{array}{l}\text { Sunway REIT Management } \\
\text { Sdn Bhd }\end{array}$ \\
\hline 9 & $\begin{array}{l}\text { Tower Real Estate } \\
\text { Investment Trust }\end{array}$ & $\begin{array}{l}\text { MTrustee Berhad } \\
\text { (formerly known as } \\
\text { AmTrustee Berhad) }\end{array}$ & $\begin{array}{l}\text { GLM REIT Management } \\
\text { Sdn Bhd }\end{array}$ \\
\hline 10 & Amanah Harta Tanah PNB & $\begin{array}{l}\text { AmanahRaya Trustees } \\
\text { Berhad }\end{array}$ & $\begin{array}{l}\text { Pelaburan Hartanah } \\
\text { Nasional Berhad }\end{array}$ \\
\hline 11 & $\begin{array}{l}\text { KLCC Real Estate } \\
\text { Investment Trust }\end{array}$ & $\begin{array}{l}\text { Maybank Trustees } \\
\text { Berhad }\end{array}$ & $\begin{array}{l}\text { KLCC REIT Management } \\
\text { Sdn Bhd }\end{array}$ \\
\hline 12 & $\begin{array}{l}\text { Pavilion Real Estate } \\
\text { Investment Trust }\end{array}$ & $\begin{array}{l}\text { MTrustee Berhad } \\
\text { (formerly known as } \\
\text { AmTrustee Berhad) }\end{array}$ & $\begin{array}{l}\text { Pavilion REIT Management } \\
\text { Sdn Bhd }\end{array}$ \\
\hline 13 & $\begin{array}{l}\text { CapitaLand Malaysia Mall } \\
\text { Trust (formerly known as } \\
\text { CapitaMalls Malaysia Trust) }\end{array}$ & $\begin{array}{l}\text { MTrustee Berhad } \\
\text { (formerly known as } \\
\text { AmTrustee Berhad) }\end{array}$ & $\begin{array}{l}\text { CapitaLand Malaysia Mall } \\
\text { REIT Management Sdn Bhd } \\
\text { (formerly known as } \\
\text { CapitaMalls Malaysia REIT } \\
\text { Management Sdn Bhd) }\end{array}$ \\
\hline 14 & $\begin{array}{l}\text { YTL Hospitality REIT } \\
\text { (formerly known as Starhill }\end{array}$ & $\begin{array}{l}\text { Maybank Trustees } \\
\text { Berhad }\end{array}$ & Pintar Projek Sdn Bhd \\
\hline
\end{tabular}




\begin{tabular}{|c|c|c|c|}
\hline & $\begin{array}{l}\text { Real Estate Investment } \\
\text { Trust) }\end{array}$ & & \\
\hline 15 & $\begin{array}{l}\text { UOA Real Estate } \\
\text { Investment Trust }\end{array}$ & RHB Trustees Berhad & $\begin{array}{l}\text { UOA Asset Management } \\
\text { Sdn Bhd }\end{array}$ \\
\hline No. & Funds Under Management & Trustee & Management Company \\
\hline 16 & $\begin{array}{l}\text { Hektar Real Estate } \\
\text { Investment Trust }\end{array}$ & $\begin{array}{l}\text { MTrustee Berhad } \\
\text { (formerly known as } \\
\text { AmTrustee Berhad) }\end{array}$ & $\begin{array}{l}\text { Hektar Asset Management } \\
\text { Sdn Bhd }\end{array}$ \\
\hline 17 & $\begin{array}{l}\text { MRCB-Quill REIT } \\
\text { (formerly known as Quill } \\
\text { Capita Trust) }\end{array}$ & $\begin{array}{l}\text { Maybank Trustees } \\
\text { Berhad }\end{array}$ & $\begin{array}{l}\text { MRCB Quill Management } \\
\text { Sdn Bhd (formerly known } \\
\text { as Quill Capita Management } \\
\text { Sdn Bhd) }\end{array}$ \\
\hline
\end{tabular}

Source: Security Commission of Malaysia, 2016

Table 1 above shows the summarization of M-REITs that are publicly listed as at November 30, 2016. Al-Aqar KPJ REIT and Al-Hadharah Boustead REIT were known to be the first Islamic REITs that were introduced in Malaysia, and then on December 2008 followed by Axis REIT which used to be a conventional REIT, transformed into Islamic REIT. Islamic REITs have to comply with the existing Syariah law requirements.

\section{The Efforts of Malaysian Government in Promoting M-REITs Industry}

In the developed market, REIT investment returns are reached around 3 to $5 \%$ on the year-on-year basis, depending on its performance of individual fund. M-REITs appear to be very attractive to investors due to that Malaysia is in the phase of a nation's rising development, as Malaysia's domestic property values can be considered in a relatively lower price range compared to other Asia's developed countries, apart from Malaysia's volume are less dense and thus, the Malaysian property sector has the growth potential. Due to this reason, it has become an opportunity with the ability of M-REITs to create standard attractive yields between 6 to $8 \%$ which can be considered to be higher than most REITs among other major developed countries.

Regionally, the feature of Asian REIT markets has more advantage than MREITs. This can be seen in other developed countries such as Hong Kong and Singapore which both have 0\% withholding tax as compared to $10 \%$ in Malaysia. For many years, the M-REITs tax system has fell behind the neighbouring countries like Singapore, which makes it to be a better attractive destination for REIT listings. Hence, a certain number of improved initiatives were made by the government and Securities Commission (SC) to publicize the Malaysian REITs market. Later on January 2005, new guidelines on MREITs were released by the Securities Commission as an effort to escalate the growth of Malaysia's capital market and initiate a vibrant and competitive REIT industry in Malaysia. The key features of the guidelines including a lesser restriction on M-REITs for the following transactions such as the limit of borrowings, acquisition of leasehold properties and acquisitions of real estates that are encumbered by financial charges. In order to stimulate the development of M-REITs, tax incentives or the exemption of chargeable income distributed to unit holders from the income tax were given to REITs or PTFs which were approved by the Securities. Besides than that, the unit holders also promoted the eligibility of tax recovery of the subsequently distributed and taxed accumulated income. On November 2005, new guidelines for the formation of Islamic REITs were also issued by the Securities Commission in order to promote the growth of Islamic capital market. The purpose for guidelines to be issued are to enhance the facilitation of the new Islamic capital market product development, therefore making Malaysia as the first jurisdiction in the global Islamic financial sector to issue such guidelines. These guidelines were expected to be set as a benchmark for the development of other Islamic REITs globally. If any M-REIT company 
distributes at least $90 \%$ of its net income, then its undistributed net income would be exempted from tax. M-REIT managers in are hoping that the government would also renounce the $10 \%$ withholding tax for resident and non-resident individuals. The reduced withholding tax of $10 \%$ on individual and noncorporate investors is only available up to December 31, 2011. Subsequently, foreign institutional investors will be taxed at $20 \%$ for M-REITs dividends that were received after the due period, whereas non-corporate investors that include resident and non-resident individuals are taxed at $15 \%$. In Malaysia's REIT Managers Association (MRMA) proposal, the deduction of the withholding tax has always been included for the government to consider during the annual budgets. In Budget 2010, the Real Property Gain Tax (RPGT) was reinstated, with the purpose to restrict the heat of speculative buying in real estates or properties. However, during that time, no announcement on any changes was made in the REIT industry. In the upcoming budget in 2011, there were high hopes regarding on the extension for the $10 \%$ of withholding tax to be reduced, if not further reduced, in order to give a broad tax direction and tax position to REIT investors beyond 2011.

Besides that, a regulatory framework for Islamic REITs has also been set up by the government as their initiative to fortify the country's reputation as the world's Islamic finance hub. The regulatory framework is also similar for both with exception that Islamic REITs must comply with the Shariah requirement, where a Shariah Advisor or Committee that acts as advisor to the Islamic REIT is required to be appointed and be the point of reference and consultations on investments that are permitted, provided under the Securities Commission guideline on Islamic REITs. Islamic REITs' distribution of income should be earned from activities that are Shariah compliant or be within the $20 \%$ benchmark, even though their distribution income can be said to be similar of conventional REITs' in which it should only be made from realized gains or realized income. The purpose of the $20 \%$ is used to evaluate the level of contribution from mixed rental payment resulted from activities that are non-Shariah compliant, such as the rental payment from premises that deals with gambling and sales of liquor. Narrowing down to today's market in Malaysia, there are 17 M-REITs being offered in Malaysia including two Islamic REITs which are Al-Aqar KPJ REIT, being the first Islamic REIT in the world and Al-Hadharah Boustead REIT, being the first Islamic plantation REIT in the world. In terms of dividend yield, both the Al-Aqar KPJ REIT and Al-Hadharah Boustead REIT rank amongst the top 3 REIT in Malaysia.

\section{Essence of Attractions for M-REITs}

According to Stewart LaBrooy, chief executive officer of Axis REIT Managers Bhd, even though in year 2009 M-REITs were facing distress impact from the global economic crisis, but the companies were still able to distribute about 70 to $80 \%$ of their net income and retained earnings to the M-REITs investors. As a result, the prime appealing factor of M-REITs is that the unit or shareholders would receive steady and generous dividend income from the distributor annually. He further states that with high dividend yields of about seven 7\% annually, low entry cost and supported with efficient level of corporate governance, MREITs should be the choice of investment for investors from all levels besides adding on that the size of assets of M-REITs has ballooned to about RM 16 billion. Furthermore, M-REITs actually enable investors to free up their time and yet having the management of the real estates into the hand of capable professionals with expertise in managing properties. They would be responsible to perform their job by maximizing the shareholders' wealth as a result of improving the yields, expanding the trusts' portfolios by acquiring more strategic assets and increasing the total market value of the assets under their management.

In addition, M-REITs would also offer investors the liquidity to be able to convert their investments easily into cash within three days, as and when the investors would like to. Partial liquidation of investment is not available for investments in physical properties, while M-REITs do allow investors to liquidate any part of the shares as required or needed, instead of all the shares held, at any point in time. Last but not least, M-REITs allow investors to have a partial ownership in larger scales real estate or properties such as retail and industrial complexes with minimal initial outlay, yet being able to reap 
benefits from the growth and development of such assets. Contrary, investment in physical properties would certainly be impossible for smaller investors such as the household or individual investors as they would have limited capacity to own and manage such physical assets. Thus, M-REITs present investors with wider range of investment opportunities within the real estate sector in Malaysia.

\section{Performance Reviews: REITs, Stock Market and Property Market}

Generally, most equity investments depend on capital gain as main source of investors' return. Whenever the share prices have a positive movement, investors will gain in return but they will suffer from losses when the share prices have a negative movement. Shares of REIT have been deemed to have less than favourable capital gains due to lower stock price fluctuations, but they have had stable and sizeable dividend payouts annually. There are certain similarities of investments in REITs and the real estate market, in which that both of them would result in ownership of the properties being invested through stock market or physical property market. However, the prime difference between them is that REITs are more liquid than real estate because with REITs, investors can easily get in and out from buying and selling of the REITs stocks through the stock market, whereas buying and selling of real estate's such as landed properties and shop lots would take much longer time for bargaining or looking for potential buyer and seller. The process of selling or buying a real estate will be more complicated and time consuming.

Study done by Corgel and Roger (1991) mentioned that the returns of REITs vary widely with the stock market in the short run spectrum, but tend to be higher correlated over longer holding periods. Still, the REITs' returns are more reflective of the changes in the rentals and values of the underlying real estates in the trusts portfolios.

Myer and Webb (1993) stated that equity REIT returns appear to be much more strongly related to closed-end funds or those on unsecuritized commercial real estates. The equity REIT index returns were found to Granger-caused the unsecuritized real estate returns for most of the real estate in National Council of Real Estate Investment Fiduciaries (NCREIF) and FRC Property Index.

Tan (2009) researched on the performance of Malaysian REIT stocks relative to Bursa Malaysia stock index from the period of June 2007 until June 2009. The correlation between Bursa indices return and Malaysia REITs return is found to be definite but low and the systematic risks of Malaysia REITs are lower than that of the broader market. In the study, Tan's results shown that the performance of M-REITs is influenced by the stock market movement over the same period through Granger Causality factor.

\section{RESEARCH MODEL AND METHODOLOGY}

\section{Research design}

In terms of the research design, this study uses quantitative data which is the secondary data to analyse the profitability of M-REITs. The variables used to assess the study of M-REITs profitability are the dividend yield, net asset value and stock market price, whereas the profitability of M-REITs is measured using ROE. Since this study consists of cross-sectional and time series data, it can be said as panel data. The panel data is able to identify the problems that may arise in a time-series data. In this study, a sample of eight M-REITs in a time period of eight years from 2008 until 2015 was collected. The sample of eight MREITs is as follows: 
Table 2: The List of M-REITs Samples Used in the Research

\begin{tabular}{|l|l|}
\hline Number & Name of Malaysia's Real Estate Investment Trust \\
\hline $\mathbf{1 .}$ & AmanahRaya Real Estate Investment Trust \\
\hline $\mathbf{2 .}$ & AmFirst Real Estate Investment Trust \\
\hline $\mathbf{3 .}$ & Amanah Harta Tanah PNB \\
\hline $\mathbf{4 .}$ & Atrium Real Estate Investment Trust \\
\hline $\mathbf{5 .}$ & Axis Real Estate Investment Trust \\
\hline $\mathbf{6 .}$ & Tower Real Estate Investment Trust \\
\hline $\mathbf{7 .}$ & UOA Real Estate Investment Trust \\
\hline $\mathbf{8 .}$ & Hektar Real Estate Investment Trust \\
\hline
\end{tabular}

All of the M-REITs firms in table 2 above are listed by the Security Commission of Malaysia. These selected firms provide complete information and data which are needed in order to carry out this study. This would ensure consistency and uniformity in the sample.

\section{Estimation Model}

The following estimation model that will be used to test the hypotheses in this research is explained as below:

$$
R O E_{i t}=\alpha+\beta_{1} D Y_{i t}+\beta_{2} N A V_{i t}+\beta_{3} S M P_{i t}+\varepsilon_{i}
$$

Where:

$\mathrm{i}$ : refers to M-REIT firm

$t:$ refers to time

ROE: refers to Return on Equity

DY: refers to Dividend Yield

NAV: refers to Net Asset Value

SMP: refers to Stock Market Price (Price-Earnings ratio as proxy for SMP)

$\alpha$ : refers to intercept

$\beta_{1}, \beta_{2}, \beta_{3}$ : refers to estimated coefficients

$\varepsilon_{i}$ : refers to error term

The parameters in this model should be in a linearity form and cannot have any relationship with the independent variables.

\section{Hypothesis}

The main hypothesis of this study is to investigate the determinant factors of M-REITs profitability. Numerous studies have attempted in investigating other several factors of the performances and returns in REITs, locally and globally. However, this study focuses on how dividend yield, net asset value and stock market price would affect the profitability of M-REITs. The hypotheses for each variable are listed as below.

H1: There is a significant relationship between dividend yield and the profitability of M-REITs. $\mathrm{H} 2$ : There is a significant relationship between net asset value and the profitability of M-REITs. 
H3: There is a significant relationship between stock market price and the profitability of M-REITs.

\section{DATA ANALYSIS AND RESULTS}

The empirical results and findings of the study in eight M-REITs listed by the Security Commission of Malaysia. were tested. The yearly data of a time period from 2009 until 2015 were used. There are few methods that used for empirical analysis which are descriptive statistic, Panel Regression Analysis and Diagnostic Test.

\section{Descriptive Statistics}

Table 3: Summary of Descriptive Statistics

\begin{tabular}{|l|c|c|c|c|c|}
\hline Variable & Observation & \multicolumn{1}{l|}{ Mix } & \multicolumn{1}{l|}{ Max } & Mean & Std. Dev \\
\hline ROE & 64 & 0.79 & 35.98 & 9.954531 & 5.169804 \\
\hline DV & 64 & 5.29 & 13.56 & 7.65625 & 1.5159 \\
\hline NAV & 64 & 0.875 & 1.937 & 1.341031 & 0.2608843 \\
\hline PER & 64 & 2.2 & 50.5 & 10.47656 & 6.316739 \\
\hline
\end{tabular}

The above table 3 shows a summarization of the descriptive statistics, in which return on equity (ROE) as a measurement of profitability represents the independent variable while dividend yield (DY), net asset value (NAV) and price earnings ratio (PER) represent the dependent variables of this study. A total number of 64 samples were collected and analysed, consisting of 8 M-REITs companies listed on the Bursa Malaysia for a period of 8 years (2008-2015). The numbers of observation, mean, standard deviation, minimum and maximum value of all variables are shown in the above table 4 . The profitability of M-REITs is measured by the return on equity (ROE). The table 3 shows that the average return on equity for 8 of the M-REITs from the year 2008 until 2015 is 9.95 , ranging from 0.79 to 35.98. The figure of the standard deviation is 5.17 which is low relative to their means. Among all the dependent variables, the price earnings ratio (PER) has the highest mean ratio of 10.48, which ranging from 2.2 to 50.5. This is followed by dividend yield (DY) with the mean ratio of 7.66, varies from 5.29 to 13.56. On the other hand, the net asset value (NAV) has the lowest mean ratio of 1.34 which ranging from 0.88 to 1.94 . By comparing the value of standard deviation of all the controlled variables, the price earnings ratio (PER) has the highest which is 6.32, followed by dividend yield (DY) with the value of 1.52 and net asset value (NAV) coming as the lowest with the value of 0.26 .

\section{Panel Regression Analysis and Diagnostic Test}

The result of Pooled OLS and Random effects model are showed in the table 4 above. In order to choose the model that is suitable for data used, Breusch and Pagan LM test has been carried out. The p-value for Breusch and Pagan Lm test shown that the value of chi square of 1.12 and its p-value of 0.2899, which is greater than the 0.05 significant level. Therefore, we would not reject the null hypothesis. This concludes that the Pooled OLS Model is more appropriate as compared to Random Effect Model. Wooldridge Test to check autocorrelation problem between the error terms among the independent variable. The result in table 4 above shows that $\mathrm{p}$ value of the autocorrelation is 0.0766 which is higher than the $5 \%$ significant value. Therefore, it is proving that there is no autocorrelation exist in the model. The next step is to conduct the multicollinearity test by using the Variance Inflation Factor (VIF). According to Gujarati and Porter (2009), there will be a multicollinearity problem in the independent variables if the variance 
inflation factor (VIF) is greater than 5. Based on table 4, the variance inflation factor (VIF) is 1.10. This indicates that the independent variables are not too inter-correlated due to the assumption that VIF is less than 5. Thus, the model does not have multicollinearity problem.

Table 4: Results of Panel Data Analysis for Fundamental Analysis.

\begin{tabular}{|l|c|c|}
\hline & Pooled OLS & Random effects \\
\hline Dividend Yield & $0.8866973 * *$ & $0.9274872 * *$ \\
& $(0.042)$ & $(0.071)$ \\
\hline Net Asset Value & -3.342821 & -3.483052 \\
& $(0.166)$ & $(0.187)$ \\
\hline Price Earnings Ratio & -0.0785665 & -0.0861523 \\
& $(\mathrm{p}=0.449)$ & $(0.514)$ \\
\hline Constant & 8.47169 & 8.75142 \\
& $(0.110)$ & $(0.233)$ \\
\hline Breusch-Pagan LM test & \multicolumn{2}{|c|}{$1.12(0.2899)$} \\
\hline Observations & 5.823 & 64 \\
\hline Wooldridge test for & $(0.0766)$ & \\
Autocorrelation & 1.10 & \\
\hline Multicollinearity (vif) & . & \\
\hline
\end{tabular}

Note: Symbols $(*, * *, * * *)$ show the statistical significance at various significant levels $(1 \%, 5 \%, 10 \%)$ respectively.

The panel regression results of Pooled OLS in table 4 above show that the dividend yield (DY) with $p$ value of 0.042 that is less than alpha of 5\% significant level. Therefore, dividend yield indicates a positive significant relationship with profitability of M-REITs. Meanwhile, the net asset value (NAV) shows a result of $p=0.166$ which is greater than alpha of $5 \%$ significant level. Hence, the net asset value revealed that there is no significant relationship profitability of M-REITs. As for price earnings ratio which is a proxy for stock market price, it has $\mathrm{p}$ value of 0.449 which is greater than alpha of $5 \%$ significant level. Therefore, resulting that the price earnings ratio has no significant relationship with profitability of M-REITs.

\section{Hypothesis results}

\section{Table 5: Hypotheses Results}

\begin{tabular}{|l|c|}
\hline Hypotheses & Action \\
\hline $\begin{array}{l}\text { H1: There is a significant relationship between dividend yield and the } \\
\text { profitability of M-REITs. }\end{array}$ & Accepted \\
\hline $\begin{array}{l}\text { H2: There is a significant relationship between net asset value and the } \\
\text { profitability of M-REITs. }\end{array}$ & Fail to accept \\
\hline $\begin{array}{l}\text { H3: There is a significant relationship between stock market price and the } \\
\text { profitability of M-REITs. }\end{array}$ & Fail to accept \\
\hline
\end{tabular}

Based on table 5, there is a positive significant relationship between dividend yield (DY) and the profitability of M-REITs measured with return on equity (ROE) in H1. However, the results of net asset value (NAV) in $\mathrm{H} 2$ and price earnings ratio (PER) in $\mathrm{H} 3$ has shown no significant relationship towards the profitability of M-REITs

\section{CONCLUSION}


Based on the panel regression results which Pooled OLS was chosen as an appropriate model after diagnostics test were performed, the findings showed that there is a positive significant relationship between dividend yield (DY) and the profitability of M-REITs measured with return on equity (ROE). However, the results of net asset value (NAV) and price earnings ratio (PER) has shown no significant relationship towards the profitability of M-REITs.

In the study, the first limitation would be the availability of data. Although the data is easily obtained from publicly available information, yet there are some M-REITS that have missing or incomplete data in some related year. Therefore, the sample size and panel observation were reduced. It affects the accuracy of the result in the study. The second limitation would be the sample size which were small due to the selected sample only covered 8 M-REITs out of a total number of 17 publicly listed MREITs in Malaysia. Therefore, it makes difficult to obtained the significant relationship from each variable. In addition to that, a total period of 8 years might not be sufficient to obtain more accurate result. A longer time frame of study would provide more accurate and relevant findings of this study.

As a conclusion, based on the findings, it is recommending and suggested to have further research to obtain more accurate and conformity results. It also recommended to extend the sample size, with the addition of more M-REITs and a longer period of year in order to have more observations. Other than that, it is recommended to construct other different types of M-REITs performance determinants to obtain more precise results and findings to enhance the reliability of the research.

\section{REFERENCES}

Ali, H.M. (2006, April). Size Effect on the Performance of Listed Real Estate Companies, International Real Estate Research Symposium (IRERS). PWTC, Kuala Lumpur, Malaysia.

Alias, A. \& Soi, T.C.Y. (2011). Performance analysis of REITs: Comparison between M-REITs and UKREITs. Journal of Surveying, Construction and Property, 2(2), 38-61.

Ambrose, P.W. and Linneman, P. (2001). REIT organizational structure and operating characteristics. Journal of Real Estate Research, 21(3), 141-162.

APREA. (2012). The investment characteristics and benefits of Asian REITs for retail investors. Retrieved from http://www.vascofm.com/ vasco167/images/dhflinders/apreareport.pdf.

Chan SH, Erickson J, Wang K. (2003). Real Estate Investment Trusts: Structure, Performance and Investment Opportunities. New York, USA: Oxford University Press.

Clayton, J., Eighholtz, P., Geltner, D. M., \& Miller, N. G. (2007). Commercial Real Estate Analysis and Investments. International Student Edition (2nd Edition ed.). USA: South-Western.

Conover, M.C., Friday, H.S., and Howton, S.W. (2000). An analysis of the cross section of returns for E REITs using a varying-risk beta model. Real Estate Economics, 28(1), 141-63.

Corgel, J.B. \& Rogers, R.C. (1991). Market trading characteristics of REITs: Tests of the stock market and hybridsecurities hypotheses. Unpublished thesis, Cornell University and University of South Carolina.

Fuscaldo, D. (2015, May 22). Before you jump into real estate, know the risks. AOL. Retrieved from http://www.aol.com/article/2015/05/22/real-estate-investments-risks/21186041/.

Gujarati, D. N., \& Porter, D. C. (2009). Basic econometrics (5th ed.). Boston: McGraw-Hill.

Hua, D., REIT Funds From Operations (FFO) Multiple Analysis, 2001, Golden Gate University.

Jalil, R.A., \& Ali, H.M. (2015). Performance determinants of Malaysian real estate investment trusts. Jurnal Teknologi (Sciences \& Engineering), 74(5), 151-159.

Keats, R. (2016, June 1). How Could an Interest Rate Hike Impact REITs? Market Realist. Retrieved from http://marketrealist.com/2016/06/interest-rate-hike-impact-reits/.

Mohamad, N.E.A, \& Zolkifli, I.A. (2014). The determinant factors of real estate investment trust (REIT)'s performance: Evidence from Asian REITs. Indonesian Capital Market Review, 6(1), 53-59. 
Myer, N.F.C. \& Webb, J.R. (1993). Return properties of equity REITs, common stocks, and commercial real estate: A comparison. The Journal of Real Estate Research, 8(1),87-107.

Newell, G. \& Acheampong, P. (2001). The dynamics of property trust risk and correlation. Paper presented at the Pacific Rim Real Estate Society (PRRES) Conference 2001.

Ong, T.S., Teh, B.H., \& Chong, M.P. (2011). A study on the performance of Malaysian real estate investment trusts from 2005-2010 by using net asset value approach. International Journal of Economics and Research, 2(1), 1-15.

Ong, T.S., Teh, B.H., Soh, C.H., \& Yan, Y.L. (2012) Malaysian real estate investment trusts: A performance and comparative analysis. International Journal of Economics and Finance, 4(5), 73 84.

Tan, S.H. (2009). Performance of Malaysia REIT stocks relative to Bursa Malaysia Stock Index. Unpublished master's thesis, Multimedia University, Malaysia.

Ting, K.H. \& Rahman, M. Y. A. (2007, January). Stability of Dividends and FFOs: The Case of REITs in Malaysia. Paper presented at the 13th Pacific Rim Real Estate Society Annual Conference Fremantle, Perth, Australia.

Yee, C.M., Jian, C.Y., Wei, K.C., \& Jing, T.W. (2011). Malaysian real estate investment trusts (M-REITs): A performance and comparative analysis.

Yu, G. (2009). Development: Performance and existing problem analysis, an overview of Asian REITs. (Unpublished master's thesis). KTH Royal Institute of Technology, Stockholm, Sweden.

Corresponding Author: Shaharudin Jakpar can be contacted at jshaharudin@unimas.my 